\title{
Drought stress inducing intraspecific variability in Potentilla tabernaemontani (Rosaceae), a calcareous grassland species
}

\author{
Mélanie Harzé*, Grégory Mahy \& Arnaud Monty
}

University of Liège, Gembloux Agro-Bio Tech, Biodiversity and landscape Unit, 2, Passage des Déportés, BE-5030 Gembloux, Belgium

*Author for correspondence: melanie.harze@ulg.ac.be

\begin{abstract}
Background and aims - Calcareous grasslands are among the most species-rich habitats in Western Europe. Populations of plant species characterizing these ecosystems are naturally submitted to high variability in environmental conditions at the very local scale, resulting in pronounced variation in functional traits. Individuals located on xeric parts of calcareous grasslands are characterized by plant traits that potentially ensure more successful performance under stressful conditions. In the context of increased frequency of summer heat waves based on climate change, our aim was to determine a possible intraspecific variability in drought response among individuals of one calcareous grassland plant species.

Methods - A greenhouse experiment was set up to follow survival of Potentilla tabernaemontani Asch. individuals according to their habitat of origin (xeric or mesic parts of Belgian calcareous grasslands) and the treatment applied (low or high drought stress).

Key results - The results demonstrated that individuals originating from xeric parts survived drought stress better than individuals from mesic parts of calcareous grasslands. Specific leaf area (SLA) of all individuals was very low in the experiment, allowing them to decrease water loss during drought stress. Leaf production was lower for individuals exposed to high drought stress while flower production was higher. That potentially expressed a trade-off between tolerance to water stress, individual growth and reproduction.

Conclusions - Local scale environmental heterogeneity deserves to be considered in conservation and restoration plans as it induces intraspecific functional variability between individuals and impacts individuals' ability to survive drought stress.
\end{abstract}

Key words - Intraspecific variability, calcareous grasslands, climate change, drought stress, greenhouse, ex situ, local scale.

\section{INTRODUCTION}

Calcareous grasslands are recognized as local biodiversity hotspots in temperate regions, hosting rare plant species (Krauss et al. 2004, Adriaens et al. 2006). Those ecosystems suffered from intensive habitat destruction and fragmentation during the last century (Prendergast et al. 1993, Poschlod \& WallisDeVries 2002, WallisDeVries et al. 2002, Adriaens et al. 2006) and are today a central issue in habitat conservation in Europe (Janssen et al. 2016). Calcareous grasslands are also characterized by high environmental variability at the very local scale, notably in terms of soil depth, soil moisture, slope and exposure, identified as main factors influencing soil hydrological status (Butaye et al. 2005, Bennie et al. 2006, Piqueray et al. 2007, Harzé et al. 2016). The total amount of available water for plants is demonstrably lower for parts of grasslands featuring thin soils $(<10 \mathrm{~cm})$, present on steep and rocky slopes with a southerly aspect and excessive drainage. Those conditions lead to high soil desiccation, high evaporation and high drought stress for herbaceous species (Alard et al. 2005, Butaye et al. 2005, Bennie et al. 2008, Dujardin et al. 2012). Xeric parts of grasslands are mostly typified by lower herbaceous cover and fewer litter accumulation than mesic parts (Butaye et al. 2005).

Climate change will likely become one of the major threats to biodiversity over the next few decades (Thuiller 2007, Bellard et al. 2012). Climate change predictions forecast that the frequency of summer heat waves will probably increase in large parts of Europe (Pachauri et al. 2014). These changes could strongly affect the structure and functions of grassland communities, especially for plants occurring on xeric parts of grasslands. Plant species that will be able to reach more suitable habitats or produce phenotypic adaptive 
responses to climate change through local adaptation or phenotypic plasticity will probably be more prone to survive on the long term (Bolnick et al. 2003, Bellard et al. 2012).

In a previous study undertaken in calcareous grasslands, a high intraspecific phenotypic variability has been exhibited at the very local scale (Harzé et al. 2016). Plant functional traits related to resource-use efficiency may vary greatly among individuals for a number of plant species, including Potentilla tabernaemontani Asch., a perennial forb that is abundant on calcareous grasslands in Belgium (Piqueray et al. 2007, Harzé et al. 2016). Specifically, individuals located on xeric parts of calcareous grasslands have been characterized by lower plant height and higher leaf tissue density (Harzé et al. 2016). Those traits potentially permit plants to maintain leaf turgor and foster more successful performance under drought stress (Niinemets 2001, Siefert 2012).

The current study aimed to evaluate if the high intraspecific phenotypic variability observed in situ in leaf traits (e.g. specific leaf area) and morphological traits (e.g. vegetative height), at the very local scale, for a calcareous grassland species (Harzé et al. 2016), may induce intraspecific differences in response to drought stress. More specifically, study aimed to evaluate if individuals located on xeric parts of calcareous grasslands survive drought stress better. Individuals of $P$. tabernaemontani were collected from xeric and mesic parts of grasslands in order to test their survival under two levels of induced drought stress in a greenhouse experiment.

\section{MATERIAL AND METHODS}

\section{Experimental design}

Potentilla tabernaemontani is a clonal perennial hemicryptophyte with prostrate, usually rooting woody stems. Yellow hermaphrodite flowers are pollinated by insects. Cross- and self-fertilization may be observed and the species usually propagates by seeds or vegetative stems. P. tabernaemontani has a European-wide distribution and may be found in dry open habitats, mainly on limestones and other basic rocks (Fitter \& Peat 1994).

Three sites were selected in southern Belgium; the Montagne-aux-buis $\left(50^{\circ} 05^{\prime} \mathrm{N}, 4^{\circ} 34^{\prime} \mathrm{E}\right)$, the Tienne Breumont $\left(50^{\circ} 04^{\prime} \mathrm{N}, 4^{\circ} 32^{\prime} \mathrm{E}\right)$ and the Sosoye hill $\left(50^{\circ} 17^{\prime} \mathrm{N}, 4^{\circ} 46^{\prime} \mathrm{E}\right)$. They are calcareous grasslands developed through traditional agropastoral practices, where xeric and mesic grasslands coexist (Butaye et al. 2005, Piqueray et al. 2007). At each site, 30 genets of $P$. tabernaemontani were randomly selected in mesic parts of grasslands and 30 genets were randomly selected in xeric parts. Genets were collected at a minimal distance of five meters from each other to assure collecting different genets. For each selected genet, two ramets (linked by stolons) were collected. The collected ramets were separated to be transplanted in pots $(8 \mathrm{~cm}$ length $\times 8 \mathrm{~cm}$ width $\times 8$ $\mathrm{cm}$ depth). Pots were previously filled with a substrate composed by $1 / 4$ of white sand and $3 / 4$ of a commercial lime compost (turf, fertilizer and lime) and water saturated. Ramets were then placed in a greenhouse in Gembloux (Belgium; $50^{\circ} 03^{\prime} 57^{\prime \prime} \mathrm{N}, 4^{\circ} 42^{\prime} 11^{\prime \prime} \mathrm{E}$; annual mean temperature c. $9^{\circ} \mathrm{C}$ ). The number of leaves of each ramet was counted at the beginning of the experiment (L0). The greenhouse was heated during winter to avoid frost. One week after transplantation, treatments were applied. For each selected genet, the two ramets were submitted to two distinct drought stress treatments during six months. The first ramet was submitted to a low stress treatment and the second ramet was submitted to a high stress treatment. Stress treatments were applied by allowing volumetric water content to decrease to a level of $30 \%$ (for the low stress) and of $15 \%$ (for the high stress) before watering the pots to saturation. A study in similar habitats indicated that soil moisture reached a maximum of approximately $50 \%$ in late autumn and winter and decreased to a minimum of roughly $20 \%$ during summer drought stress periods (Niklaus et al. 1998). Soil water content was measured three times a week using a volumetric moisture probe (TRIME®-PICO32, IMKO) in 36 randomly selected pots of each treatment. All pots of the treatment were watered if the mean volumetric water content of the 36 pots was below $30 \%$ for the low stress treatment and below $15 \%$ for the high stress treatment. Position of pots in the greenhouse was randomly changed every week.

\section{Data collection and analysis}

Ramet survival and flower production were monitored three times a week over six months. Survival was defined as complete leaf senescence and no ramet regrowth during two weeks after plant rehydration. The number of days between the beginning of the experiment and the production of the first flower of each ramet was calculated (first flowering) and the total number of flowers produced by each ramet was counted. The number of leaves of each ramet was tallied at the beginning (L0) and at the end (L1) of the experiment for surviving ramets in order to calculate a foliar increase ratio: $\ln \mathrm{L} 1$ - $\ln \mathrm{L} 0$ (Hunt 2017).

The regulation of water loss through leaves can be expressed by several key leaf functional traits (Wright et al. 2001, Ackerly 2004) and, for example, be reflected through lower specific leaf area (SLA; Volaire 2008, Poorter et al. 2009). After six months, two leaves produced during the experiment by surviving ramets were collected for SLA measurement, i.e., the one-sided area of a fresh leaf divided by its oven-dried mass (in $\mathrm{mm}^{2} \mathrm{mg}^{-1}$ ). We followed the leaf trait measurement protocol of Garnier et al. (2001). Fresh leaves were scanned following a minimum of $6 \mathrm{~h}$ of rehydration and leaf area was measured using ImageJ imaging software (Abràmoff et al. 2004). Leaves were then oven-dried at $60^{\circ} \mathrm{C}$ for $72 \mathrm{~h}$ and weighed to the nearest $10^{-1} \mathrm{mg}$ (Mettler Toledo ${ }^{\circledR}$, Viroflay, France).

In order to compare ramet performance (number of flowers produced, first flowering, foliar increase ratio and SLA) according to their habitat of origin (xeric or mesic part) and the drought stress treatment applied (low or high drought stress), three-way ANOVAs were performed based on site (random, three modalities), habitat of origin (fixed, two modalities) and stress treatment (fixed, two modalities) as crossed factors. As survival was a binary variable, a generalized linear model $(\mathrm{glm})$ was fitted using the binomial family followed by an analysis of deviance with site, habitat of origin and stress treatment as crossed factors. The site effect was never significant (all p-values $>0.55$ ), so we conducted the same 
Table 1 - Survival and traits of Potentilla tabernaemontani across habitat of origin and stress treatment.

Deviance analysis (survival) and two-way analysis of variance (ANOVAs; number of flowers produced, first flowering, foliar increase ratio and SLA) performed with habitat of origin (fixed, two modalities) and stress treatment (fixed, two modalities) as crossed factors. Means are given according to habitat of origin or stress treatment. Significantly different means are followed by different letters and significant $\mathrm{p}$-values $(<0.05)$ are in bold.

\begin{tabular}{|c|c|c|c|c|c|c|c|}
\hline & \multirow{2}{*}{$\begin{array}{c}\text { factors interaction } \\
\text { p-value }\end{array}$} & \multicolumn{3}{|c|}{ habitat of origin } & \multicolumn{3}{|c|}{ stress treatment } \\
\hline & & xeric parts & mesic parts & p-value & low stress & high stress & p-value \\
\hline survival & 0.627 & $0.85^{\mathrm{b}}$ & $0.75^{\mathrm{a}}$ & 0.017 & $0.85^{\mathrm{b}}$ & $0.75^{\mathrm{a}}$ & 0.016 \\
\hline Nn of flowers produced & 0.819 & $6.0^{\mathrm{a}}$ & $6.7^{\mathrm{a}}$ & 0.237 & $5.8^{\mathrm{a}}$ & $6.9^{\mathrm{b}}$ & 0.028 \\
\hline first flowering (days) & 0.496 & $88.9^{\mathrm{a}}$ & $88.0^{\mathrm{a}}$ & 0.789 & $85.9^{\mathrm{a}}$ & $91.1^{\mathrm{a}}$ & 0.108 \\
\hline foliar increase ratio & 0.116 & $1.08^{\mathrm{a}}$ & $1.20^{\mathrm{a}}$ & 0.064 & $1.23^{\mathrm{b}}$ & $1.05^{\mathrm{a}}$ & 0.008 \\
\hline $\operatorname{SLA}\left(\mathrm{mm}^{2} \mathrm{mg}^{-1}\right)$ & 0.297 & $7.8^{\mathrm{a}}$ & $8.1^{\mathrm{a}}$ & 0.157 & $7.7^{\mathrm{a}}$ & $8.2^{\mathrm{a}}$ & 0.067 \\
\hline
\end{tabular}

analysis with habitat of origin and stress treatment as crossed factors. Deviance and ANOVAs were followed by a pairwise comparison of means (Tukey's test). Foliar increase ratio and SLA were $\log$ transformed to meet the assumptions of the statistical analyses. ANOVAs were performed with Minitab ${ }^{\circledR}$ 17.1.0 and analysis of deviance were performed with R 3.1.0 (R Development Core Team 2014).

\section{RESULTS}

The interaction between habitat of origin (mesic or xeric parts of grasslands) and stress treatment (low or high) was not significant for any measurements (table 1). Survival probabilities were significantly higher for individuals collected from xeric parts of grasslands compared to individuals coming from mesic parts of grasslands ( $p$-value $=0.017$, table 1) and were significantly reduced for individuals exposed to high drought stress compared to low drought stress ( $p$-value $=0.016$, table 1). Individuals from xeric parts of grasslands growing under low drought stress survived better (fig. 1A).

Habitat of origin had no effect on the number of flowers produced, first flowering (number of days between the beginning of the experiment and the production of the first flower), foliar increase ratio and SLA, while stress treatment had no effect on first flowering and SLA (table 1). The foliar increase ratio was lower for individuals exposed to high drought stress ( $p$-value $=0.008$, table 1$)$, particularly for individuals from xeric parts (fig. 1D). The number of flowers produced was higher for individuals exposed to high drought stress (p-val$\mathrm{ue}=0.028$, table 1) but no significant differences between means were highlighted by the pairwise comparison of means (Tukey's test, fig. 1C). First flowering and SLA were similar among habitat of origin and treatment (figs 1C \& E). SLA values were particularly low for both treatments with values comprised between 3.6 and a maximum of $18.4 \mathrm{~mm}^{2} \mathrm{mg}^{-1}$ with a mean of approximately $8.0 \mathrm{~mm}^{2} \mathrm{mg}^{-1}$ for both treatments.

\section{DISCUSSION}

Populations of $P$. tabernaemontani are naturally exposed to high small-scale variability in environmental conditions in calcareous grasslands (Bennie et al. 2008, Harzé et al. 2016), leading to high in situ variability of functional traits at the very local scale (Harzé et al. 2016). Individuals grown in xeric parts of grasslands are smaller and characterized by lower specific leaf area than individuals in mesic parts of grasslands, which should ensure more successful performance under stressful conditions. Indeed, low SLA is related to high investment in structural tissues, which allow plants to maintain leaf turgor under drought stress (Niinemets 2001, Siefert 2012). Conservative species, that exhibit low SLA, corresponding to dense leaf tissues and low growth rates, exhibit high resource conservation (Albert et al. 2010).

Intraspecific variability in drought stress responses was evaluated in a greenhouse experiment for the calcareous grassland plant species P. tabernaemontani. The findings confirmed that drought response was variable according to the habitat origin of the species. Individuals originating from xeric parts of grassland survived better both low and high drought stress conditions. This could be because of low SLA, allowing individuals to decrease water loss under drought stress. Values of SLA were particularly low for all individuals at the end of the experiment (maximum value: $18.36 \mathrm{~mm}^{2}$ $\left.\mathrm{mg}^{-1}\right)$ compared to in situ observation $\left(32 \mathrm{~mm}^{2} \mathrm{mg}^{-1}\right.$; Harzé et al. 2016). However, in this experiment, SLA did not differ across habitats of origin or stress treatments and therefore did not explain the observed differences in individual survival. Resistance to drought stress could be understood by variability in other (not measured) physiological traits linked to water use efficiency, such as root traits or stomatal density (Cornelissen et al. 2003, Pérez-Harguindeguy et al. 2013). Indeed, previous slowly increasing stresses may induce physiological adjustments in plant that may protect them from a future stress abruptly imposed (Kozlowski \& Pallardy 2002). 
Although phenological changes are more heavily investigated in response to mean change in climate than to extreme events, plant species may also respond to drought by modifying their phenology, such as earlier onset of leaf development or flowering (Parmesan \& Yohe 2003, Root et al. 2003, Reyer et al. 2013). This was not the case for P. tabernaemontani individuals as the period of time before the first flowering was similar for individuals from xeric or mesic parts of grasslands and among treatments.

The foliar increase ratio also presented high variability among individuals, illustrating the ability of species to produce distinct phenotypes in response to the environment. In arid environments, a negative relationship between plant capacity to tolerate drought and growth potential can be predicted. This could be because off a trade-off between tolerance to water stress and individual growth (Chapin 1980, Reznick 1985, Loehle 1987). Plants with a higher growth potential may be characterized by physiological traits that, in principle, should result in poor performance under intense drought conditions and vice versa (Fernández \& Reynolds 2000). This could justify the differences in leaf production between treatments with individuals reducing their production of leaves under high drought stress. Reducing leaves production under stressful environment could also be the results of an allocation strategy between growth and reproduction. Indeed, plants may allocate greater proportion of their resource to reproduction than to vegetative growth under environmental stress (Aronson et al. 1993). That could explain that $P$. tabernaemontani produced more flowers under high drought stress.

The observed variability in plant traits can stem from multiple factors. It can be the result of variability between genotypes originating from evolutionary processes and local adaptation (Fisher 1930, Hughes et al. 2008), or it can be based on acclimation or phenotypic plasticity; i.e. the potential of each individual genotype to produce multiple phenotypes under various environmental conditions (DeWitt et al. 1998). Those mechanisms may act simultaneously and the observed variability in plant traits can be the consequence of different combinations of genetic and environmental variabilities (Bolnick et al. 2003). Carefully designed experiments are necessary to assess whether the observed intraspecific variation is brought
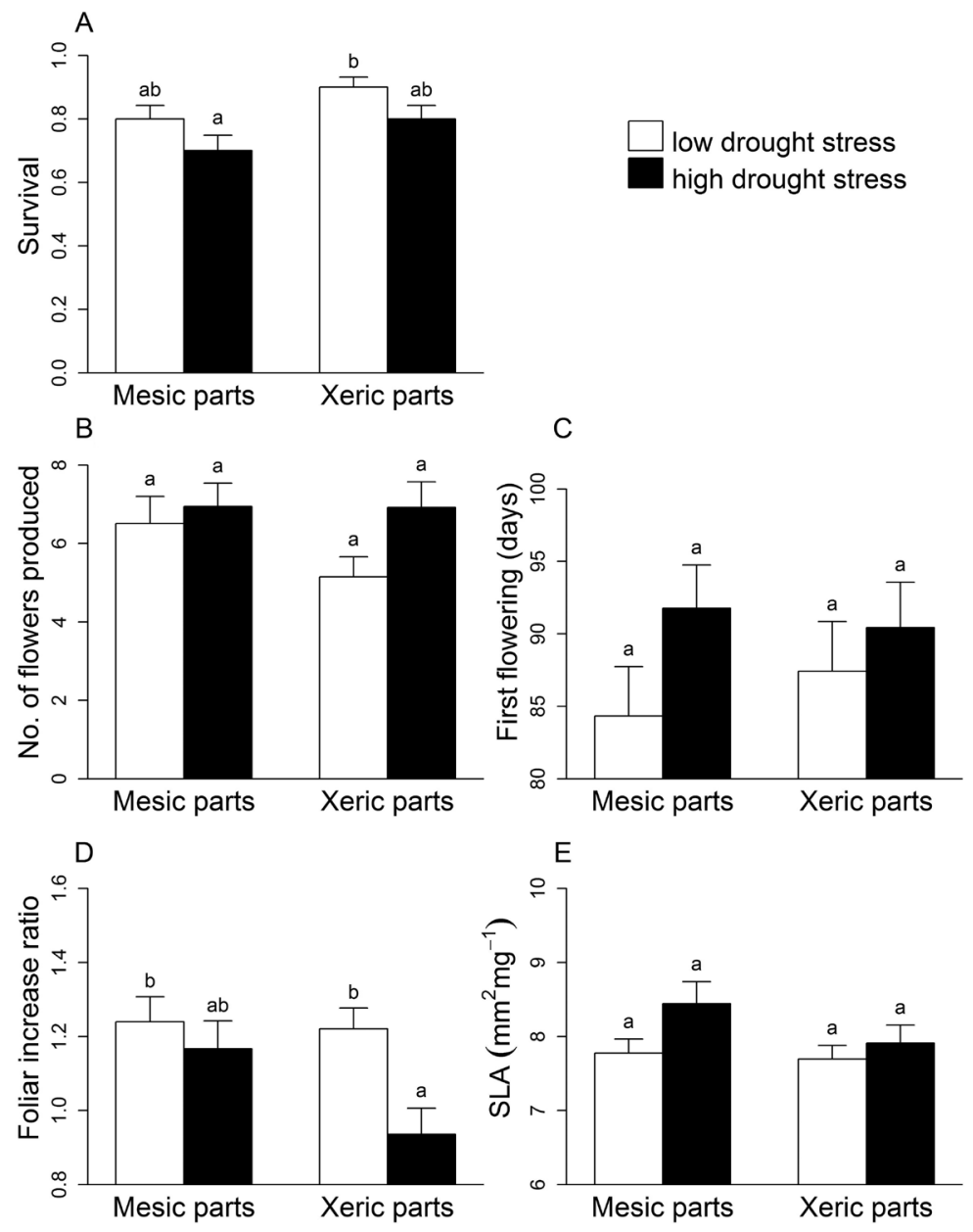

Figure 1 - Crossed effect of habitat of origin and stress treatment. Means and standard errors of survival (A), number of flowers produced (B), first flowering (C), foliar increase ratio (D) and SLA (E) of Potentilla tabernaemontani individuals across habitat of origin (mesic or xeric parts of calcareous grasslands) and stress treatment (low stress in white and high stress in black). On each graph, significantly different means (crossed Tukey's test) are followed by different letters. 
about by plasticity or local adaptation. However, whatever the causes of the observed traits variability in calcareous grassland plant species, the greenhouse experiment demonstrated that individuals of $P$. tabernaemontani from very stressful environments survive drought stress better. It may represent a challenge for species conservation in the face of future climate change. However, this study should be completed with data from other calcareous grasslands species to be able to draw general conclusion. Calcareous grasslands have suffered intensive fragmentation in the past (Poschlod \& WallisDeVries 2002, Piqueray et al. 2011) and restoration projects have taken place all over Europe in order to stop the decline of this habitat. Considering local-scale environmental heterogeneity in conservation and restoration plans is required to maintain large intra-specific variability in the landscape and thereby a variety of genotypes and phenotypes that can buffer plant species from future environmental changes (Wellstein et al. 2013, Mitchell \& Bakker 2014).

\section{ACKNOWLEDGEMENTS}

We would like to thank the Service public de Wallonie Département de la Nature et des Forêts for field access and Stephane Tombeur for his help concerning site selection with regard to management practices. We also want to thank the two anonymous reviewers for their pertinent comments on a previous version of the manuscript.

\section{REFERENCES}

Abràmoff M. D., Magalhães P.J., Ram S.J. (2004) Image processing with imageJ. Biophotonics International 11: 36-41.

Ackerly D.D. (2004) Functional strategies of chaparral shrubs in relation to seasonal water deficit and disturbance. Ecological Monographs 74: 25-44. https://doi.org/10.1890/03-4022

Adriaens D., Honnay O., Hermy M. (2006) No evidence of a plant extinction debt in highly fragmented calcareous grasslands in Belgium. Biological Conservation 133: 212-224. https://doi. org/10.1016/j.biocon.2006.06.006

Alard D., Chabrerie O., Dutoit T., Roche P., Langlois E. (2005) Patterns of secondary succession in calcareous grasslands: can we distinguish the influence of former land uses from present vegetation data? Basic and Applied Ecology 6: 161-173. https://doi. org/10.1016/j.baae.2005.01.010

Albert C.H., Thuiller W., Yoccoz N.G., Douzet R., Aubert S., Lavorel S. (2010) A multi-trait approach reveals the structure and the relative importance of intra- vs. interspecific variability in plant traits. Functional Ecology 24: 1192-1201. https://doi. org/10.1111/j.1365-2435.2010.01727.x

Aronson J., Kigel J., Shmida A. (1993) Reproductive allocation strategies in desert and Mediterranean populations of annual plants grown with and without water stress. Oecologia 93: 336342. https://doi.org/10.1007/BF00317875

Bellard C., Bertelsmeier C., Leadley P., Thuiller W., Courchamp F. (2012) Impacts of climate change on the future of biodiversity. Ecology Letters 15: 365-377. https://doi.org/10.1111/j.14610248.2011.01736.x

Bennie J., Hill M.O., Baxter R., Huntley B. (2006) Influence of slope and aspect on long-term vegetation change in British chalk grasslands. Journal of Ecology 94: 355-368. https://doi. org/10.1111/j.1365-2745.2006.01104.x
Bennie J., Huntley B., Wiltshire A., Hill M.O., Baxter R. (2008) Slope, aspect and climate: spatially explicit and implicit models of topographic microclimate in chalk grassland. Ecological Modelling 216: 47-59. https://doi.org/10.1016/j.ecolmodel.2008.04.010

Bolnick D.I., Svanbäck R., Fordyce J.A., Yang L.H., Davis J.M., Hulsey C.D., Forister M.L. (2003) The ecology of individuals: incidence and implications of individual specialization. The American Naturalist 161: 1-28. https://doi.org/10.1086/343878

Butaye J., Honnay O., Adriaens D., Delescaille L.-M., Hermy M. (2005) Phytosociology and phytogeography of the calcareous grasslands on Devonian limestone in southwest Belgium. Belgian Journal of Botany 138: 24-38.

Chapin F.S. (1980) The mineral nutrition of wild plants. Annual Review of Ecology and Systematics 11: 233-260. https://doi. org/10.1146/annurev.es.11.110180.001313

Cornelissen J.H.C., Lavorel S., Garnier E., Díaz S., Buchmann N., Gurvich D.E., Reich P.B., ter Steege H., Morgan H.D., van der Heijden M.G.A., Pausas J.G., Poorter H. (2003) A handbook of protocols for standardised and easy measurement of plant functional traits worldwide. Australian Journal of Botany 51: 335-380. https://doi.org/10.1071/BT02124

DeWitt T.J., Sih A., Wilson D.S. (1998) Costs and limits of phenotypic plasticity. Trends in Ecology \& Evolution 13: 77-81. https://doi.org/10.1016/S0169-5347(97)01274-3

Dujardin G., Bureau F., Vinceslas-Akpa M., Decaëns T., Langlois E. (2012) Soil functioning in a mosaic of herbaceous communities of a chalky environment: temporal variations of water availability and N dynamics. Plant and Soil 360: 197-213. https://doi.org/10.1007/s11104-012-1234-3

Fernández R.J., Reynolds J.F. (2000) Potential growth and drought tolerance of eight desert grasses: lack of a trade-off? Oecologia 123: 90-98. https://doi.org/10.1007/s004420050993

Fisher R.A. (1930) Genetics, mathematics, and natural selection. Nature 126: 805-806. https://doi.org/10.1038/126805a0

Fitter A.H., Peat H.J. (1994) The Ecological Flora Database. Journal of Ecology 82: 415-425. https://doi.org/10.2307/2261309

Garnier E., Shipley B., Roumet C., Laurent G. (2001) A standardized protocol for the determination of specific leaf area and leaf dry matter content. Functional Ecology 15: 688-695. https:// doi.org/10.1046/j.0269-8463.2001.00563.x

Harzé M., Mahy G., Monty A. (2016) Functional traits are more variable at the intra- than inter-population level: a study of four calcareous dry-grassland plant species. Tuexenia 36: 321-336.

Hughes A.R., Inouye B.D., Johnson M.T.J., Underwood N., Vellend M. (2008) Ecological consequences of genetic diversity. Ecology Letters 11: 609-623. https://doi.org/10.1111/j.14610248.2008.01179.x

Hunt R. (2017) Growth analysis, individual plants. In: Thomas B., Murray B.G., Murphy D.J. (eds) Encyclopedia of applied plant sciences. Volume 1: plant physiology and development: 421429. 2nd Ed. Oxford, UK, Elsevier. https://doi.org/10.1016/ B978-0-12-394807-6.00226-4

Janssen J.A.M., Rodwell J.S., Criado M. G., Gubbay S., Haynes T., Nieto A., Sanders N., Landucci F., Loidi J., Ssymank A., Tahvanainen T., Valderrabano M., Acosta A., Aronsson M., Arts G., Attorre F., Bergmeier E., Bijlsma R.-J., Bioret F., BiţăNicolae C., Biurrun I., Calix M., Capelo J., Čarni A., Chytrý M., Dengler J., Dimopoulos P., Essl F., Gardfjell H., Gigante D., Giusso del Galdo G., Hájek M., Jansen F., Jansen J., Kapfer J., Mickolajczak A., Molina J.A., Molnár Z, Paternoster D., Piernik A., Poulin B., Renaux B., Schaminée J.H.J., Šumberová K., Toivonen H., Tonteri T., Tsiripidis I., Tzonev R., Valachovič 
M. (2016) European Red List of habitats - Part 2. Terrestrial and freshwater habitats. Brussels, European Commission. Available from https://portals.iucn.org/library/sites/library/files/ documents/2016-079-vol.2.pdf [accessed 14 Nov. 2017].

Kozlowski T.T., Pallardy S.G. (2002) Acclimation and adaptive responses of woody plants to environmental stresses. The Botanical Review 68: 270-334. https://doi.org/10.1663/00068101(2002)068[0270:AAAROW]2.0.CO;2

Krauss J., Klein A.-M., Steffan-Dewenter I., Tscharntke T. (2004) Effects of habitat area, isolation, and landscape diversity on plant species richness of calcareous grasslands. Biodiversity and Conservation 13: 1427-1439. https://doi.org/10.1023/ B:BIOC.0000021323.18165.58

Loehle C. (1987) Partitioning of reproductive effort in clonal plants: a benefit-cost model. Oikos 49: 199-208. https://doi. org/10.2307/3566027

Mitchell R.M., Bakker J.D. (2014) Quantifying and comparing intraspecific functional trait variability: a case study with Hypochaeris radicata. Functional Ecology 28: 258-269. https:// doi.org/10.1111/1365-2435.12167

Niinemets Ü. (2001) Global-scale climatic controls of leaf dry mass per area, density, and thickness in trees and shrubs. Ecology 82: 453-469. https://doi.org/10.1890/00129658(2001)082[0453:GSCCOL]2.0.CO;2

Niklaus P.A., Spinnler D., Körner C. (1998) Soil moisture dynamics of calcareous grassland under elevated $\mathrm{CO}_{2}$. Oecologia 117: 201-208. https://doi.org/10.1007/s004420050649

Pachauri R.K., Allen M.R., Barros V.R., Broome J., Cramer W., Christ R., Church J.A., Clarke L., Dahe Q., Dasgupta P., Dubash N.K., Edenhofer O., Elgizouli I., Field C.B., Forster P., Friedlingstein P., Fuglestvedt J., Gomez-Echeverri L., Hallegatte S., Hegerl G., Howden M., Jiang K., Jimenez Cisneroz B., Kattsov V., Lee H., Mach K.J., Marotzke J., Mastrandrea M.D., Meyer L., Minx J., Mulugetta Y., O’Brien K., Oppenheimer M., Pereira J.J., Pichs-Madruga R., Plattner G.K., Pörtner H.O., Power S.B., Preston B., Ravindranath N.H., Reisinger A., Riahi K., Rusticucci M., Scholes R., Seyboth K., Sokona Y., Stavins R., Stocker T.F., Tschakert P., van Vuuren D., van Ypserle J.P. (2014) Climate change 2014: synthesis report. Contribution of working groups I, II and III to the fifth assessment report of the Intergovernmental Panel on Climate Change. Geneva, IPCC. Available from http://www.ipcc.ch/report/ar5/syr/ [accessed 14 Nov. 2017].

Parmesan C., Yohe G. (2003) A globally coherent fingerprint of climate change impacts across natural systems. Nature 421: $37-$ 42. https://doi.org/10.1038/nature01286

Pérez-Harguindeguy N., Díaz S., Garnier E., Lavorel S., Poorter H., Jaureguiberry P., Bret-Harte M.S., Cornwell W.K., Craine J.M., Gurvich D.E., Urcelay C., Veneklaas E.J., Reich P.B., Poorter L., Wright I.J., Ray P., Enrico L., Pausas J.G., de Vos A.C., Buchmann N., Funes G., Quétier F., Hodgson J.G., Thompson K., Morgan H.D., ter Steege H., van der Heijden M.G.A., Sack L., Blonder B., Poschlod P., Vaieretti M.V., Conti G., Staver A.C., Aquino S., Cornelissen J.H.C. (2013) New handbook for standardised measurement of plant functional traits worldwide. Australian Journal of Botany 61: 167-234. https://doi.org/10.1071/ BT12225

Piqueray J., Bisteau E., Bottin G., Mahy G. (2007) Plant communities and species richness of the calcareous grasslands in southeast Belgium. Belgian Journal of Botany 140: 157-173.

Piqueray J., Bisteau E., Cristofoli S., Palm R., Poschlod P., Mahy G. (2011) Plant species extinction debt in a temperate biodiversity hotspot: community, species and functional traits ap- proaches. Biological Conservation 144: 1619-1629. https://doi. org/10.1016/j.biocon.2011.02.013

Poorter H., Niinemets Ü., Poorter L., Wright I.J., Villar R. (2009) Causes and consequences of variation in leaf mass per area (LMA): a meta-analysis. New Phytologist 182: 565-588. https://doi.org/10.1111/j.1469-8137.2009.02830.x

Poschlod P., WallisDeVries M.F. (2002) The historical and socioeconomic perspective of calcareous grasslands - Lessons from the distant and recent past. Biological Conservation 104: 361-376. https://doi.org/10.1016/S0006-3207(01)00201-4

Prendergast J.R., Quinn R.M., Lawton J.H., Eversham B.C., Gibbons D.W. (1993) Rare species, the coincidence of diversity hotspots and conservation strategies. Nature 365: 335-337. https://doi.org/10.1038/365335a0

R Development Core Team (2014) R: a language and environment for statistical computing. Vienna, R Foundation for Statistical Computing. Available from https://www.r-project.org/ [accessed 14 Nov. 2017].

Reyer C.P.O., Leuzinger S., Rammig A., Wolf A., Bartholomeus R.P., Bonfante A., de Lorenzi F., Dury M., Gloning P., Abou Jaoudé R., Klein T., Kuster T.M., Martins M., Niedrist G., Riccardi M., Wohlfahrt G., de Angelis P., de Dato G., François L., Menzel A., Pereira M. (2013) A plant's perspective of extremes: terrestrial plant responses to changing climatic variability. Global Change Biology 19: 75-89. https://doi.org/10.1111/ gcb. 12023

Reznick D. (1985) Costs of reproduction: an evaluation of the empirical evidence. Oikos 44: 257-267. https://doi. org $/ 10.2307 / 3544698$

Root T.L., Price J.T., Hall K.R., Schneider S.H., Rosenzweig C., Pounds J.A. (2003) Fingerprints of global warming on wild animals and plants. Nature 421: 57-60. https://doi.org/10.1038/ nature 01333

Siefert A. (2012) Incorporating intraspecific variation in tests of trait-based community assembly. Oecologia 170: 767-775. https://doi.org/10.1007/s00442-012-2351-7

Thuiller W. (2007) Biodiversity: climate change and the ecologist. Nature 448: 550-552. https://doi.org/10.1038/448550a

Volaire F. (2008) Plant traits and functional types to characterise drought survival of pluri-specific perennial herbaceous swards in Mediterranean areas. European Journal of Agronomy 29: 116-124. https://doi.org/10.1016/j.eja.2008.04.008

WallisDeVries M.F., Poschlod P., Willems J.H. (2002) Challenges for the conservation of calcareous grassland in northwestern Europe: integrating the requirements of flora and fauna. Biological Conservation 104: 265-273. https://doi.org/10.1016/ S0006-3207(01)00191-4

Wellstein C., Chelli S., Campetella G., Bartha S., Galiè M., Spada F., Canullo R. (2013) Intraspecific phenotypic variability of plant functional traits in contrasting mountain grasslands habitats. Biodiversity and Conservation 22: 2353-2374. https://doi. org/10.1007/s10531-013-0484-6

Wright I.J., Reich P.B., Westoby M. (2001) Strategy-shifts in leaf physiology, structure and nutrient content between species of high- and low-rainfall, and high- and low-nutrient habitats. Functional Ecology 15: 423-434. https://doi.org/10.1046/ j.0269-8463.2001.00542.x

Manuscript received 24 Mar. 2017; accepted in revised version 14 Nov. 2017.

Communicating Editor: Olivier Chabrerie. 